\title{
Strategi Pembelajaran Pendidikan Agama Islam dengan Metode Dirosah Aqil Baligh (Dirab) dalam Mengembalikan Fitrah Seksual Remaja
}

Nurhayati Syarifudin ${ }^{1}$, M. Ubaidillah Alghifary Slamet ${ }^{2}$, Syahida Rena ${ }^{3}$

1,2,3 Institut Ilmu Al-Qur'an (IIQ) Jakarta, Indonesia

E-mail:nunksyarif@gmail.com, ubaidillah@iiq.ac.id, Syahidah.rena@iiq.ac.id

Article Info
Article Histo
Received: 2021
Revised: 2022
Published: 2022

Keywords:
Learning;
Education;
Islam;
Dirab method;
Sexual Fitrah.

\section{Abstract}

This study describes the study of learning strategies for Islamic religious education using the Dirosah Aqil Baligh (Dirab) method in restoring adolescent sexual nature with a case study of students at SMA Negeri 1 Setu, Bekasi Regency. There have been deviations in the sexual disposition of adolescents in the midst of society that have been carried out openly and fairly, such as courtship, sex outside of marriage (zina), abortion, and others. This is caused by many factors, including the lack of knowledge about proper sex education among them, pornography and the large influence of foreign cultures in Indonesia. This is where the importance of launching a PAI learning strategy with the DIRAB method to restore their sexual nature to conform to Islam. The method used in this study uses a descriptive quantitative method or approach with an experimental method that examines the effect of certain variables in a tightly controlled group. With the technique of writing using purposive sampling. The results of this study indicate that the reality of deviant sexual behavior by students at SMA Negeri 1 Bekasi is caused by a lack of closeness to religious values, lack of parental roles, watching and reading, make-up and dressing styles that are not in accordance with Islam, wrong associations, and lack of knowledge of sex education. The application of the DIRAB method resulted in an increase in students' knowledge of up to $25 \%$, this is indicated by the average score before treatment was 74 and the score after was 91.

\section{Abstrak}

\section{Sejarah Artikel}

Diterima: 2021-12-27

Direvisi: 2022-01-22

Dipublikasi: 2022-02-02

Kata kunci:

Pembelajaran; Pendidikan:

Agama Islam;

Metode Dirab;

Fitrah Seksual.
Penelitian ini menjelaskan tentang kajian terhadap strategi pembelajaran pendidikan agama islam dengan metode dirosah aqil baligh (Dirab) dalam mengembalikan fitrah seksual remaja dengan studi kasus peserta didik SMA Negeri 1 Setu Kabupaten Bekasi. Telah terjadi penyimpangan disposisi seksual remaja di tengah-tengah masyarakat yang telah dilakukan secara terbuka dan wajar, seperti pacaran, seks di luar nikah (zina), aborsi, dan lain-lain. Hal ini disebabkan oleh banyak faktor antara lain kurangnya pengetahuan tentang pendidikan seks yang benar di antara mereka, pornografi dan besarnya pengaruh budaya asing di Indonesia. Di sinilah pentingnya meluncurkan strategi pembelajaran PAI dengan metode DIRAB untuk mengembalikan fitrah seksual mereka agar sesuai dengan Islam. Metode yang digunakan dalam kajian ini menggunakan metode atau pendekatan deskriptif kuantitatif dengan metode eksperimen yang menguji pengaruh variabel-variabel tertentu dalam kelompok yang dikontrol ketat. Dengan teknik penulisan menggunakan purposive sampling. Hasil penelitian ini menunjukkan bahwa realitas perilaku seksual menyimpang yang dilakukan siswa di SMA Negeri 1 Bekasi disebabkan karena kurangnya kedekatan dengan nilai-nilai agama, kurangnya peran orang tua, menonton dan membaca, tata rias dan gaya berpakaian yang tidak sesuai dengan Islam, pergaulan yang salah, dan kurangnya pengetahuan pendidikan seks. Penerapan metode DIRAB terjadi peningkatan pengetahuan siswa hingga $25 \%$, hal ini ditunjukkan dengan nilai rata-rata sebelum perlakuan 74 dan nilai sesudahnya menjadi 91.

\section{PENDAHULUAN}

Fitrah seksual merupakan suatu hal kodrat yang ada pada setiap manusia. Fitrah seksual sejatinya bukan hanya sekedar karunia dan nikmat yang Allah berikan tapi juga merupakan amanah yang harus senantiasa dijaga, diarahkan, dibimbing dan butuh pengetahuan serta pendidikan tentangnya agar dorongan seksual dapat sesuai dengan fitrah kemanusiaan dan akal sehat, dalam artian tersalurkan pada dan dengan cara yang benar dan sesuai ajaran agama Islam, dengan demikian seksual bukan hanya semata untuk memperoleh kepuasan semata tapi maknanya lebih dari itu yakni berkaitan dengan kebutuhan manusia untuk berketurunan. Meski sudah ada rambu-rambu dalam Islam untuk 
masalah seksual namun ada saja penyimpanganpenyimpangan seksual yang terjadi dan manusia yang memiliki perilaku abnormal, seperti santer atau marak dibicarakan belakangan ini di tanah air seperti lesbian, gay, biseksual, trans-gender (LGBT) dan Perilaku seksual lainnya yang bertujuan untuk menarik perhatian lawan jenis, contohnya antara lain merayu, menggoda, bersiul dan lain-lain. Aktivitas seksual adalah kegiatan yang dilakukan dalam upaya memenuhi dorongan seksual atau kesenangan organ kelamin atau seksual melalui berbagai perilaku, contohnya berfantasi, masturbasi, dan berhubungan intim (Sebayang, 2018).

Salah satu dari sekian banyak penyebab penyimpangan perilaku seksual remaja yang pertama adalah tayangan televisi yang ada turut andil memberikan rangsangan seksual remaja saat ini, seperti FTV (Film Televisi) yang begitu digandrungi para remaja seolah menjadi sebuah tuntunan untuk melakukan percintaan yang tidak sewajarnya. Menurut (Sofyan, 2020) bahwa salah satu penyimpangan seksual remaja tergambar pula pada berbagai media sosial yang memunculkan gambar tidak senonoh, hal ini akan berdampak buruk pada kaum remaja saat ini jika selalu disajikan dengan berbagai macam tontonan yang semua mengarah pada cinta terlarang maka generasi kita akan terjebak pada budaya pergaulan bebas dan larut dalam faham hedonisme dan liberal dimana tujuan hidup mereka hanya mencari kebahagiaan melalui kesenangan-kesenangan dan kenikmatan belaka sehingga mereka mengagungkan prinsip-prinsip kebebasan tanpa ada batasan norma dan agama (Arifudin, 2020).

Survei Rencana Pembangunan Jangka menengah Nasional (RPJMN) tahun 2017, baik remaja laki-laki maupun perempuan mengaku pertama kali punya pacar di usia 16 tahun, mereka yang punya pacar kebanyakan mengaku pernah melakukan hubungan seksual dibanding remaja pada umumnya, kemudian Data Survei Demografi dan Kesehatan Indonesia (SDKI) tahun 2017 mengungkap sekitar $2 \%$ remaja wanita usia 1524 tahun dan $8 \%$ remaja pria rentang usia yang sama, telah melakukan hubungan seksual sebelum menikah. Sebanyak 11\% diantaranya mengaku mengalami kehamilan yang tidak diinginkan "jumlah ini yang tercatat, bisa jadi diluar sana yang tidak terdata lebih banyak," menurut peneliti Badan Penelitian dan Pengembangan Kesehatan (Balitbangkes) dari Kementrian Kesehatan, Tin Afifah, S. K. M., M. K. M. pada selasa $(9 / 10 / 2018)$.
Survey diatas menjadi satu tolak ukur betapa remaja Indonesia mengalami krisis dekadensi moral dan ini menjadi tamparan bagi para orang tua, pendidik dan masyarakat pada umumnya agar terus menjaga para anaknya dari bahaya pergaulan bebas yang saat ini menjadi sesuatu yang dianggap lumrah, bahkan hamil diluar nikah pun menjadi hal yang tidak lagi asing. Menurut (Irwansyah, 2021) bahwa perkembangan arus zaman, perkembangan media elektronik dan media cetak menjadi faktor buruknya pergaulan remaja saat ini, sebab yang berikutnya remaja melakukan perilaku seksual adalah karena masyarakat saat ini berada dalam masa transisi, dimana kemajuan dunia teknologi telah merubah struktur masyarakat dan juga pandangan hidupnya. Menurut (Nasser, 2021) bahwa dampak negative kemajuan teknologi mempermudah akses pada berbagai hal termasuk situssitus pornografi. Nilai-nilai moral mengalami pergeseran, sehingga yang dahulu dianggap dapat diterima, kini belum tentu demikian dan sebaliknya. Salah satu segi pergeseran moral tersebut ialah pergeseran dalam nilai moral seksual yang terjadi terutama dikalangan remaja. Nilai-nilai moral seksual yang dahulu dianggap tabu atau bertentangan dengan norma-norma agama, tidak demikian lagi oleh sebagian kaum remaja saat ini, dengan demikian memberikan bimbingan seks pada remaja merupakan suatu yang sangat penting dan perlu.

Banyak kesimpang siuran pendapat tentang arti pendidikan seks, ada yang berpendapat bahwa pendidikan seks sama dengan penerangan tentang anatomi fisiologi seks manusia, tentang bahaya-bahaya penyakit kelamin dan sebagainya. Pendapat lain mengatakan bahwa pendidikan seks sama dengan sex play hanya perlu diberikan kepada orang dewasa, beberapa masalah dan sebab yang dipaparkan diatas mendorong penulis untuk melakukan penelitian terhadap peserta didik pada SMA Negeri 1 Setu Kabupaten Bekasi. Metode Dirosah Aqil Baligh (DIRAB) tergagas berharap bisa memberikan solusi atas permasalah seksual remaja khususnya di kalangan peserta didik SMA Negeri 1 Setu Kabupaten Bekasi dan bagi masyarakat pada umumnya.

\section{METODE PENELITIAN}

Jenis penelitian ini dilakukan dengan pendekatan kuantitatif. Menurut (Rahayu, 2020) bahwa pendekatan kuantitatif bertujuan untuk menguji teori, membangun fakta, menunjukan hubungan antar variabel, memberikan deskripsi 
statistik, menaksir dan meramalkan hasilnya. Data dalam penelitian ini bersifat kuantitatif atau angka-angka statistik (Tanzeh, 2011), menggunakan cara penelitian eksperimen meniliti pengaruh variabel tertentu dalam suatu kelompok dalam kondisi yang dikontrol secara ketat (Nasution, 2003). Menurut (Bahri, 2021) bahwa dalam desain eksperimen terdapat kelompok yang disebut dengan kelompok eksperimen, yaitu kelompok yang sengaja dipengaruhi oleh variabel-variabel tertentu misalnya diberi latihan, disamping itu ada pula kelompok kontrol, yaitu kelompok yang tidak dipengaruhi variabel-variabel, misalnya tidak diberi latihan. Adanya kelompok kontrol dimaksud sebagai pembanding sampai sejauh mana terjadi perubahan akibat variabel-variabel eksperimen itu (Hanafiah, 2021).

Sedangkan desain eksperimen yang digunakan adalah desain post eksperimen. Menurut Moleong dalam (Supriani, 2022) bahwa desain ini terdapat dua kelompok yang dipilih, kemudian diberi pretest untuk mengetahui keadaaan awal adakah perbedaan antara kelompok eksperimen dan kelompok control, hasil pretest yang baik bila nilai eksperimen tidak berbeda secara signifikan. Pengaruh perlakuan adalah (02-01)-(04-03). Pada penilitian ini menggunakan purposive sampling dilakukan dengan mengambil orang-orang yang terpilih betul oleh peneliti menurut ciri-ciri spesifik yang dimiliki oleh sampel itu (Arikunto, 2006), teknik ini dilakukan karena beberapa pertimbangan, keterbatasan waktu, tenaga dan dana sehingga tidak dapat mengambil sampel yang besar. Menurut Moleong dalam (Arifudin, 2021) bahwa sampling purposive adalah sampel yang dipilih dengan cermat sehingga relevan dengan desain penelitian. Penelitian akan berusaha agar dalam sampel itu dapat wakil-wakil dari segala lapisan populasi (Nasution, 2003). Adapun sampling yang digunakan pada penelitian tesis ini adalah kelas $\mathrm{X}$ Bahasa dengan jumlah siswa 38 orang sebagai kelompok eksperimen dan kelas X IPS 1 sebagai kelas kontrol dengan jumlah siswa 38 orang. Pengambilan sampel eksperiment kelas X Bahasa karena Hasil kuesioner pengetahuan awal nya sangat rendah dibandigkan dengan kelas lain. Begitu juga kelas $\mathrm{X}$ IPS 1 memiliki hasil pengetahuan yang sangat rendah dan cukup banyak peserta didik yang memiliki perilaku seksual remaja.

\section{HASIL DAN PEMBAHASAN}

Pada Bagian ini akan dibahas tentang strategi pembelajaran dam pendidikan agama islam, fitrah seksual, konsep pendidikan seksual remaja dan metodenya, tujuan pendidikan seks, materimateri pendidikan seksual remaja menurut syari'at islam serta deskripsi metode dirosah aqil baligh, berikut penjelasannya:

1. Strategi Pembelajaran Dalam Pendidikan Agama Islam

Dalam sebuah pembelajaran dibutuh-kan sebuah strategi yang baik agar kegiatan pemebelajaran tersebut menyena-ngkan dan dapat diserap oleh peserta didik dengan baik dan proses tujuan kegiatan belajarpun tercapai (Darmayani, 2021). Secara etimologi, strategi berasal dari kata yunani yaitu "strategos" yang memiliki makna yaitu usaha untuk mencapai keme-nangan dalam suatu peperangan. Strategi pembelajaran jika diterapkan dalam kontek aktivitas pembelajaran dalam pendidikan agama Islam bisa diterjemahkan menjadi sebagai berikut:

a) Mengidentifikasikan serta menetapkan spesifikasi dan kualifikasi perubahan tingkah laku dan kepribadian peserta didik sebagaimana yang diharapkan.

b) Memilih sistem pendekatan pembela-jaran berdasarkan aspirasi dan panda-ngan hidup masyarakat.

c) Memilih dan menetapkan metode pembelajaran yang dianggap paling tepat dan efektif sehingga dapat dijadikan pegangan oleh para guru pendidikan agama Islam dalam kegiatan mengajar-nya.

d) Menetapkan norma-norma dan batas minimal keberhasilan atau kriteria standar keberhasilan sehingga dapat di-jadikan pedoman oleh guru pendidikan agama Islam dalam melakukan evaluasi hasil kegiatan pembelajaran, yang selanjutnya menjadi umpan balik bagi penyempurnaan sistem instruksional yang bersangkutan secara keseluruhan (Kurniawan, 2017).

\section{Fitrah Seksual}

Konsep fitrah menurut pendapat para ulama berbeda-beda sesuai dengan yang diyakini dan difahami oleh para ahli dan ulama, perbedaan ini semua bersumber dari sebuah ayat Allah berfirman yang artinya: "Maka hadapkanlah wajahmu dengan lurus kepada agama Allah; (tetaplah atas) fitrah Allah yang telah mencip-takan manusia menurut fitrah itu, tidak ada peubahan pada fitrah Allah, (itulah) agama yang lurus; tetapi 
kebanyakan manusia tidak mengetahui." (QS. Ar-Rum [30]: 30), Banyak potensi yang Allah ciptakan dan titipkan pada diri manusia sebagi bekal dan modal untuk menjalani proses kehidupan sesuai dengan fitrah-Nya, dari mulai fitrah beragama, fitrah berakal, fitrah bermoral, fitrah belajar, fitrah seksual, fitrah eko-nomi, fitrah sosial, fitrah kemerdekaan dan fitrah-fitrah yang lainnya merupakan potensi atau bekal yang Allah berikan kepada setiap manusia karena fitrah-fitrah tersebut menjadi kebutuhan atau hajat bagi setiap manusia yang harus senantiasa dipenuhi kebutuhan-nya setiap hari selama manusia itu hidup. Menurut Al-Ghazali Fitrah merupakan dasar bagi manusia yang diperolehnya sejak lahir dengan memiliki keistimewaan-keistimewaan salah satunya adalah Dorongan biologis yang berupa syahwat, nafsu, dan tabiat (Al-Ghazali, 2000). Menurut Harry Santosa fitrah seksual adalah Setiap anak dilahirkan dengan jenis kelamin lelaki dan perempuan. Bagi manusia, jenis kelamin akan berkembang menjadi peran seksualitasnya. Bagi anak perempuan akan menjadi peran keperempuanan dan kebundaan sejati. Bagi anak lelaki menjadi peran kelelakian dan keayahan sejati (Santosa, 2018), dari beberapa pendapat diatas dapat disimpulkan bahwa sebenarnya fitrah seksualitas adalah tentang bagaimana seseorang berfikir, merasa dan bersikap sesuai fitrahnya sebagai lelaki sejati atau sebagai perempuan sejati artinya anak harus tahu apa beda perempuan dengan laki-laki dan apa yang biasanya perempuan dan laki-laki lakukan sesuai dengan nilai-nilai di masyarakatnya (gender) dan nilai-nilai agamanya.

3. Konsep Pendidikan Seksual Remaja dan Metodenya

Pembahasan mengenai pendidikan seks remaja tidak lepas dari pro-kontra bagi yang kontra beranggapan bahwa masalah seks adalah tabu, kotor, cabul dan porno. Betapapun banyak orang beranggapan bahwa masalah seks adalah hal tabu, namun dalam keseharian kita tidak bisa lepas dari kebutuhan seks yang merupakan kebutuhan dasar setiap manusia (Miqdad, 1981). Pengetahuan tentang seks dapat diperoleh melalui informasi-informasi yang diterima oleh panca indera manusia, baik dari sumber-sumber yang benar maupun yang salah. Pengetahuan tentang seks yang baik dan benar dapat di- peroleh melalui sex education atau pendidikan seks.

Abdullah Nasih Ulwan mengemukakan bahwa yang dimaksud pendidikan seks adalah: "memberikan pengajaran, penger-tian, dan keterangan yang jelas kepada anak ketika ia sudah memahami hal-hal yang berkaitan dengan seks dan pernikahan". (Ulwan, 2012). Salim Sahil mengemukakan bahwa pendidikan seks adalah penjelasan bimbingan serta pengasuhan laki-laki dan perempuan dari sejak anak-anak sampai dewasa perihal per-gaulan antar kelamin umumnya dan kehidupan seksual khususnya, agar mereka dapat melakukan sebagaimana mestinya (Miqdad, 1981), dari pendapat diatas dapat difahami bahwa pendidikan seks adalah penjelasan tentang bimbingan seputar tujuan dan fungsi dari pendidikan seks sehingga mereka bisa berlaku sebagaimana mestinya menurut agama dan norma kehidupan.

\section{Tujuan Pendidikan Seks}

Secara umum tujuan pendidikan seks sesuai dengan kesepakatan International Conference of Education and Family Planing tahun 1962, adalah untuk menghasilkan manusia dewasa yang dapat menjalankan kehidupan yang bahagia karena dapat menyesuaikan diri dengan masyarakat dan lingkungannya, serta bertanggung jawab terhadap dirinya dan terhadap orang lain (Miqdad, 1981). Ninuk Widyantoro mengemukakan bahwa "Tujuan akhir dari pendidikan seks adalah pencegahan kehamilan di luar perkawinan". (Sarwono, 1981). Harlina Martono mengutip pendapat kirkendall, bahwa tujuan pendidikan seks adalah sebagai berikut, membentuk pengertian tentang perbedaan seks antara laki-laki dan perempuan dalam keluarga, pekerjaan dan seluruh kehidupan, yang selalu berubah dan berbeda dalam tiap masyarakat dan kebudayaan, tentang peranan seks dalam kehidupan manusia dan keluarga, hubungan antara seks dan cinta, perasaan seks dalam perkawinan dan sebagainya, memahami diri sendiri sehubungan dengan fungsi dan kebutuhan seks, disini pendidikan seks menjadi pendidikan mengenai seksualis manusia, jadi seks dalam arti sempit dan Membantu peserta didik dalam mengembangkan kepribadiannya sehingga mampu untuk mengambil keputusan yang bertanggung jawab, misalnya memilih jodoh, hidup berkeluarga atau tidak, perceraian, kesusilaan dalam seks dan lain-lain (Sarwono, 
1981), dari beberapa pendapat diatas mengenai tujuan pendidikan seks adalah Membentuk manusia dewasa yang bertanggung jawab terhadap lingkungan dan masyarakat, Agar mengetahui pencegahan kehamilan diluar nikah, Memberikan pengertian tentang peranan, fungsi dam tujuan seks dan mengembangkan kepribadiannya hingga mampu bertanggung jawab atas segala keputusan yang diambil.

5. Materi-materi Pendidikan Seksual Remaja Menurut Syari'at Islam

Dikatakan oleh Ayip Syafrudin bahwa pendidikan seksual dalam Islam merupakan bagian integral dari pendidikan akidah, akhlak dan ibadah, pendidikan seksual tidak bisa lepas dari tiga unsur diatas, jika pendidikan seksual jauh dari tiga unsur tersebut maka akan mengalami ketidakjelasan arah dan menimbulkan kesesatan dan penyimpangan dari tujuan asal dan hanya akan berdasarkan hawa nafsu manusia semata (Miqdad, 1981). Ali Akbar mengaitkan pendidikan seks dengan akidah dan menegaskan bahwa sex education apapun macamnya dan isinya tidak akan mengurangi kejahatan seksual tanpa disertakan dan didasarkan iman, bahwa Tuhan memberikan bimbingan tentang kehidupan seksual serta mengadakan pengawasan yang sangat teliti terhadap pelanggaran dan akan memberikan hukuman yang setimpal dan adil (Miqdad, 2001).

Materi khusus pendidikan seks menurut syari'at Islam, sebagaimana dikemukakan oleh Ayip Syafruddin, berisi pokok sebagai berikut: Menanamkan jiwa maskulinitas pada anak laki-laki dan jiwa feminitas pada anak perempuan, mengenalkan mahramnya, mendidik agar selalu menjaga pandangan mata, mendidik agar tidak melakukan ikhtilat, mendidik agar tidak melakukan jabatan tangan atau bersentuhan dengan lawan jenis yang bukan mahramnya, Mendidik agar tidak melakukan khalwat, Mendidik etika berhias, Mendidik cara berpakaian islami.

\section{Metode Pendidikan Seksual}

Berbicara masalah metode pendidikan seks menurut syariat Islam harus harus juga sesuai dengan tujuan manusia hidup menurut ajaran Allah SWT, untuk mencapai tujuan itu dibutuhkan metode atau cara yang dapat menghantarkan kepada arah tujuannya. Metode pendidikan seks menurut syariat Islam tidak bisa lepas dengan metode pendidikan Islam, sebab pendidikan seks dalam syariat Islam merupakan bagian dari pendidikan akhlak, sedangkan pembentukan manusia berahlak mulia merupaka sebagian dari tujuan pendidikan dalam Islam (Miqdad, 2001).

Adapun pendidikan seks pada remaja adalah:

a) Metode ceramah digunakan untuk menjelaskan semua materi pendidikan seks dengan kata-kata yang jelas dan kekinian sehingga dapat dipahami oleh para remaja.

b) Metode tanya jawab atau metode bertanya dengan maksud mengajar, Adapun tujuan umum dari penggunaan metode ini adalah memberikan stimulus kepada anak untuk berfikir dan berusaha mencari jawaban dari pertanyaan atau mengingat kembali apa yang dipelajari.

c) Metode dengan memberikan keteladanan, Metode ini digunakan untuk mengajarkan pendidikan seks dengan cara mengaitkan pendidikan seks dengan pendidikan akhlak. Pelaksanaan dari metode keteladanan ini adalah seorang guru/pendidik memberikan penjelasan tentang syari'at yang mengatur hubungan antara laik-laki dan perempuan, misalnya materi menjaga pandangan mata, larangan agara tidak melakukan khalwat, cara berpakaian secara islami dan materi tentang khalwat.

d) Metode dengan mau'idhah yaitu suatu teknik mendidik dengan memberikan nasihat-nasihat baik kepada anak didik, misalnya nasihat untuk tidak melakukan penyimpangan seksual seperti homo seks, lesbian, onani dan masturbasi. Kemudian memberikan nasihat tentang larangan zina dan larangan berpacaran.

e) Metode melatih diri untuk mengamalkan, Metode ini menitik tekankan pada upaya melatih diri dan pembiasaan dengan perlahan dan bertahap dengan penuh kesadaran. Metode ini dapat diterapkan pada pendidikan seks dalam latihan menjaga pandangan, tidak berjabat tangan dengan yang bukan mahramnya dan melatih agar tidak berkhalwat dengan lawan jenis yang bukan mahram (Miqdad, 2001).

Dari beberapa metode diatas peneliti lebih cenderung kepada metode mau'idhoh yaitu dengan pendekatan melalui nasihat-nasihat yang bisa diawali dengan kisah-kisah inspiratif atau siroh orang-orang terdahulu agar bisa bercermin dari masa lalu kemudian diambil hikmah dari apa yang pernah terjadi dari 
kesalahan orang-orang terdahulu, kemudian kita titik tekankan berikutnya dengan pendekatan metode melatih diri untuk mengamalkan, pada hakikatnya metode ceramah juga dibutuhkan dalam hal pendidikan seks untuk menjelaskan hal-hal yang berkaitan dengan pendidikan seks namun metode ceramah ini seringnya menjadi hal yang membosankan dan monoton, maka jika ingin menggunakan metode ceramah harus memiliki strategi khusus yang memiliki daya tarik tersendiri bagi yang mendengarkan. Misalnya penjelasan dibarengi dengan penggunaan power point yang menarik dan video-video yang berkaitan dengan materi yang dibahas sebagai bentuk refleksi dan penguatan terhadap materi dari metode ceramah atau juga metode ceramahnya bisa didiringi dengan games yang berkaitan dengan materi dan nantinya bisa diambil hikmah dan pelajarannya oleh peserta didik.

\section{Deskripsi metode dirosah aqil baligh}

Metode Dirosah Aqil Baligh (DIRAB) ini merupakan salah satu metode pendidikan seksual pada remaja, metode ini akan dilaksanakan dengan klasikal maupun perkelompok dengan materi-materi yang berkaitan dengan kewajiban dan larangan bagi seseorang yang sudah aqil baligh serta diberikan motivasi bagaimana seharusnya menjadi seorang pemuda dalam Islam serta diberikan materi tarbiyah jinsiyah dan materi fitrah seksual dalam Islam baik itu melalui kisah dari $\mathrm{Al}$ Qur'an, hadis maupun siroh nabawiyah. Metode ini juga dibarengi dengan mengasah fitrah serta motorik yang harus ada pada masing-masing setiap jenis kelamin perempuan dan laki-laki dan membahas materi leadership. Metode DIRAB juga merupakan kegiatan pembelajaran untuk memecahkan masalah remaja dengan cara diskusi, curhat dan solusi, karena pada hakikatnya ketika mulai aqil baligh ada rasa penasaran dan libido meningkat dalam diri mereka, namun mereka tidak mempunyai pegangan dan tempat untuk mengungkapkan dan bertanya akan hal-hal yang terjadi pada perkembangan masa aqil baligh para remaja pada umumnya. Adapun orang tua yang seharusnya menjadi fasilitator untuk menjelaskan dan membimbing masa aqil baligh mereka untuk menjadi seorang pemuda Islam yang baik itu tidak pernah menyentuh pada ranah penejelasan seputar seksual karena merasa tabu.
Metode DIRAB adalah salah satu upaya mengembalikan fitrah seksual remaja dengan memberikan Pendidikan seks secara islami dan membimbing agar mereka dapat mencapai Aqil Baligh dengan baik, karena bagaimanapun fitrah seksual yang sudah ada dalam diri setiap manusia harus diarahkan melalui Pendidikan dan bimbingan yang sesuai dengan ajaran agama islam dan perintah Allah agar senantiasa berkembang kea rah yang lebih baik dan tercapai tujuan penciptaan fitrah itu sendiri, adapun materi-materi metode DIRAB mengambil dan menyadur pendapat beberpa ahli, menurut Ayip Syafrudin bahwa pendidikan seksual dalam Islam merupakan bagian integral dari pendidikan akidah, akhlak dan ibadah.

Materi khusus pendidikan seks menurut syariat Islam berisi pokok sebagai berikut:

a) Menanamkan jiwa maskulinitas pada anak laki-laki dan jiwa feminitas pada anak perempuan.

b) Mengenalkan mahramnya.

c) Mendidik agar selalu menjaga pandangan mata.

d) Mendidik agar tidak melakukan ikhtilat.

e) Mendidik agar tidak melakukan jabatan tangan atau bersentuhan dengan lawan jenis yang bukan mahramnya.

f) Mendidik agar tidak melakukan khalwat.

g) Mendidik etika berhias.

h) Mendidik cara berpakaian islami.

Penelitian ini diawali dengan menyebarkan kuesioner yang sudah dibuat peneliti ke beberapa kelas untuk mendapatkan data awal, setelah data dan hasil skor dari jawaban kuisioner didapatkan maka peneliti mulai melaksanakan penelitian kepada kelas yang mendapatkan sesuai hasil skor pengetahuan terendah dari kelas-kelas yang ada dan dilaku-kan treatment secara bertahap.

Berdasarkan hasil analisis data terhadap metode DIRAB untuk mengembalikan fitrah seksual remaja di SMA Negeri 1 Setu, hasil tes sebelum diberikan treatment dan tes setelah diberikan treatment, beradasarkan tabel nilai pengetahuan kelompok treatment sebelum treatment dengan jumlah 38 koresponden menunjukan interpretasi tinggi berjumlah 19 item soal dan interpretasi sangat tinggi berjumlah 8 item soal rata-rata yang tertera pada tabel dengan index 76.30 dan interpretasi tinggi. Hasil ini sejalan dengan konsep yang dikemukakan (Ulfah, 2022) bahwa tingkat pendidikan 
seseorang yang rendah akan dapat menghambat perkembangan sikapnya terhadap penerimaan, informas dan nilai-nilai yang baru diperkenalkan begitupun sebalik-nya yang terjadi pada penelitian ini. Penelitian ini menunjukkan bahwa sebelum dilakukan treatment dengan Metode DIRAB masih ada diantara peserta didik yang memiliki penge-tahuan yang rata-rata tinggi, pada tabel nilai hasil penelitian setelah treatment, terdapat penurunan pada kelompok treatment menunjukan kategori interpretasi tinggi ber-jumlah 1 item soal dan sebaliknya terdapat peningkatan pada kategori interpretasi sangat tinggi berjumlah 26 item soal, penelitian ini menunjukan sebelum dilakukan treatment rata-rata dengan index 76.30 dan setelah dilakukan treatment menunjukan rata-rata dengan index 90.94 dengan interpretasi sangat tinggi.

Dari hasil uji Postest setelah dilakukan pembinaan Metode DIRAB dengan memadu-kan edukasi seks islami dan alat reproduksi diketahui meningkat secara signifikan dan memiliki hubungan linier serta membuktikan bahwa metode DIRAB dapat mempengaruhi perilaku seksual dan pengetahuan seks edukasi Islam peserta didik SMA Negeri 1 Setu Kabupaten Bekasi dan mengembalikan fitrah seksual remaja. Hasil penelitian ini sejalan dengan penelitian yang dilakukan (Panjiasih, 2019) yang menyatakan bahwa pengetahuan agama dan hukum pernikahan dini mempengaruhi perilaku seksual, yakni semakin tinggi pengetahuna agama seseorang maka semakin tinggi tinggi pula perilaku cegah seks, metode DIRAB membuktikan dengan pembinaan seks edukasi Islam dan alat reproduksi dapat menaikan nilai pengetahuan peserta didik dan menurunkan perilaku seksual remaja agar kembali kepada fitrah seksual menurut Islam.

Tabel 1. Rerata skor sebelum dan setelah diberikan Treatment

\begin{tabular}{lcc}
\hline \multicolumn{1}{c}{ Data } & $\begin{array}{c}\text { Sebelum } \\
\text { diberikan } \\
\text { treatment }\end{array}$ & $\begin{array}{c}\text { Setelah } \\
\text { diberikan } \\
\text { treatment }\end{array}$ \\
\hline Nilai tertinggi & 88 & 99 \\
Nilai terendah & 62 & 64 \\
Rata-rata & 76 & 91 \\
$\begin{array}{l}\text { Jumlah peserta } \\
\text { didik }\end{array}$ & 38 & 38 \\
\hline
\end{tabular}

Berdasarkan tabel diatas dapat diketahui bahwa nilai rata-rata keseluruhan sebelum diberikan treatment yaitu 77 dengan kategori cukup dan nilai rata-rata setelah diberikan treatment yaitu
91 dengan kategori sangat baik, dengan demikian dapat disimpulkan bahwa pemberian treatment pada strategi pembelajaran Pendidikan Agama Islam (PAI) dapat meningkatkan pengetahuan peserta didik pada fitrah seksual remaja. Uji hipotesis dilakukan setelah uji normalitas, dalam penelitian ini uji hipotesis menggunakan uji-t, uji-t ini dilakukan untuk mengetahui apakah terdapat perbedaan yang signifikan terhadap skor sebelum diberikan treatment dan setelah diberikan treatment pada peserta didik kelas X di SMAN 1 Setu Kabupaten Bekasi, hasil perhitungan uji-t disajikan pada tabel di bawah ini:

Tabel 2. Hasil uji hipotesis (uji-t)

\begin{tabular}{cc}
\hline Data & Uji-t \\
\hline Mean & 27,85 \\
$\mathbf{t}_{\text {hitung }}$ & 1 \\
$\mathbf{t}_{\text {table }}$ & 0,95 \\
\hline
\end{tabular}

Berdasarkan hasil analisis pada tabel di atas hasil uji-t data sebelum diberikan treatment dan setelah diberikan treatment pada taraf signifikan 0,05 dengan derajat kebebasan $\mathrm{df}=\mathrm{n}-1=38-1=37$ diperoleh $\mathrm{t}$ hitung=1,0 sedangkan $\mathrm{t}$ tabel $=0,95$, dalam melakukan pengujian tersebut diajukan hipotesis berikut ini. Berdasarkan kriteria tersebut, maka diperoleh thitung $>$ ttabel, yaitu 1,0 $>0,95$ sehingga $\mathrm{H}_{0}$ ditolak dan Ha diterima, dengan demikian dapat disimpulkan bahwa terdapat peningkatan pengetahuan peserta didik dalam mengembalikan fitrah seksual remaja dengan menerapkan treatment pada strategi pembelajaran pendidikan agama Islam, artinya dari uji hipotesis yang dilakukan menunjukan bahwa terdapat pengaruh yang lebih baik terhadap pengeta-huan peserta didik dalam mengembalikan fitrah seksual remaja dengan menerapkan treatment pada strategi pembelajaran pendidikan agama Islam.

\section{SIMPULAN DAN SARAN}

\section{A. Simpulan}

Berdasarkan pemaparan pada penelitian ini dapat disimpulkan bahwa aplikasi metode DIRAB dalam mengembalikan fitrah seksual remaja dengan menerapkan treatment menunjukkan bahwa terdapat pengaruh yang lebih baik, hal ini bisa dilihat dari hasil nilai rata-rata nilai pada kelas kontrol antara sebelum treatment 74 dan rata-rata nilai setelah treatment 91, dan kenaikan pengetahuan sampai $25 \%$.

\section{B. Saran}


Pembahasan terkait penelitian kajian terhadap strategi pembelajaran pendidikan agama islam dengan metode dirosah aqil baligh (Dirab) dalam mengembalikan fitrah seksual remaja dengan studi kasus peserta didik SMA Negeri 1 Setu Kabupaten Bekasi bahwa kepada seluruh Guru pendidikan agama agar lebih inovatif lagi dalam mengembangkan metode pembelajaran pendidikan agama Islam baik dalam kelas maupun di luar kelas agar pembelajaran agama Islam bisa lebih menyenangkan, jadilah manajer kelas yang mampu memimpin peserta didik menuju perubahan-perubahan baru untuk meningkatkan kualitas peserta didik yang lebih baik, berkarakter islami, intelektual, religius dan berprestasi baik imtak maupun iptek dibidang akademik maupun non akademik.

\section{DAFTAR RUJUKAN}

Al-Ghazali. (2000). Ihya Ulumuddin. Semarang: Toha Putra.

Arifudin, O. (2020). Psikologi Pendidikan (Tinjauan Teori Dan Praktis). Bandung: Widina Bhakti Persada.

Arifudin, 0. (2021). Implementasi Balanced Scorecard dalam Mewujudkan Pendidikan Tinggi World Class. Edumaspul: Jurnal Pendidikan, 5(2), 767-775.

Arikunto, S. (2006). Prosedur Penelitian Suatu Pendekatan Praktik. Jakarta : Rieneka Cipta.

Bahri, A. S. (2021). Pengantar Penelitian Pendidikan (Sebuah Tinjauan Teori dan Praktis). Bandung: Widina Bhakti Persada.

Chomaria. (2012). Pendidikan Seks Untuk Anak. Solo: Aqwam Jembatan Ilmu.

Darmayani, S. (2021). Pembelajaran Digital. Bandung : Widina Bhakti Persada.

Fathirma'ruf, n., Asmedy, A., Budiman, B., \& Imansyah, M. (2021). PENGEMBANGAN EMODUL BERBANTUAN APLIKASI TEAM VIEWER DAN WHATSAPP UNTUK EFEKTIVITAS PRAKTIKUM JARAK JAUH DIMASA PANDEMI COVID-19. Kwangsan: Jurnal Teknologi Pendidikan, 9(2), 204--219. doi:https://doi.org/10.31800/jtp.kw.v9n2.p $\underline{204--219}$
Hanafiah, H. (2021). Pelatihan Software Mendeley Dalam Peningkatan Kualitas Artikel Ilmiah Bagi Mahasiswa. Jurnal Karya Abdi Masyarakat, 5(2), 213-220.

Irwansyah, R. (2021). Perkembangan Peserta Didik. Bandung : Widina Bhakti Persada.

Kurniawan. (2017). Strategi dan Metode Pembelajaran Pendidikan Agama Islam. Yogyakarta: MPI UIN.

Miqdad. (1981). Pendidikan Seks Bagi Remaja. Yogyakarta: Mitra Pustaka.

Miqdad. (1997). Pendidikan Seks Bagi Remaja Menurut Hukum Islam. Yogyakarta: Mitra Pustaka.

Miqdad. (2001). Pendidikan Seks Bagi Remaja. Cet. 3. Yogyakarta: Mitra Pustaka.

Muhaimin. (2004). Paradigma Pendidikan Islam, Upaya Mengefektifkan Pendidikan Agama Islam di Sekolah. Bandung: PT Remaja Rosda Karya.

Na'im, Z. (2021). Manajemen Pendidikan Islam. Bandung: Widina Bhakti Persada.

Nasser, A. A. (2021). Sistem Penerimaan Siswa Baru Berbasis Web Dalam Meningkatkan Mutu Siswa Di Era Pandemi. Biormatika: Jurnal Ilmiah Fakultas Keguruan Dan Ilmu Pendidikan, 7(1), 100-109.

Nasution. (2003). Metode Research. Jakarta: Bumi Aksara.

Panjiasih. (2019). Peningkatan Pengetahuan Faktor-faktor yang Mempengaruhi Perilaku Seks dalam Upaya Pencegahan Seks Pranikah Pada Siswa-siswi SMPN 77 dan SMAN 77 Jakarta Pusat. Jurnal Pengabdian Kepada Masyarakat., 4(2), 1-11.

Rahayu, Y. N. (2020). Program Linier (Teori Dan Aplikasi). Bandung : Widina Bhakti Persada.

Santosa. (2018). Fitrah Based Education Versi 3.0. Bekasi : Yayasan Cahaya Mutiara Timur.

Sarwono. (1981). Seksualitas dan Fertilitas Seksual Remaja. Jakarta: CV. Rajawali. 
Sebayang. (2018). Perilaku Seksual Remaja. Yogyakarta: Deepublish.

Sofyan, Y. (2020). Peranan Konseling Dosen Wali Dalam Meningkatkan Motivasi Belajar Mahasiswa Di Perguruan Tinggi Swasta Wilayah LLDIKTI IV. Jurnal Bimbingan Dan Konseling Islam, 10(2), 237-242.

Supriani, Y. (2022). Peran Manajemen Kepemimpinan dalam Pengelolaan Lembaga Pendidikan Islam. JIIP-Jurnal Ilmiah Ilmu Pendidikan, 5(1), 332-338.
Tanzeh. (2011). Metodologi Penelitian Praktis. Jakarta: Teras.

Ulfah, U. (2022). Kepemimpinan Pendidikan di Era Disrupsi. JIIP-Jurnal Ilmiah Ilmu Pendidikan, 5(1), 153-161.

Ulwan. (2012). Pedidikan Anak dalam Islam. Bandung : Insan Kamil. 